\title{
The regulation of body weight: lessons from the seasonal animal
}

\author{
Peter J. Morgan* and Julian G. Mercer \\ Aberdeen Centre for Energy Regulation and Obesity (ACERO), Rowett Research Institute, Greenburn Road, Bucksburn, \\ Aberdeen AB21 9SB, UK
}

\begin{abstract}
The hypothalamus is a major regulatory centre involved in the control of many important physiological axes. One of these axes is the regulation of ingestive behaviour. Recent work using a combination of genetic-mutant mouse models together with targeted gene deletions has contributed much to our understanding of how neural pathways of the hypothalamus are involved in the regulation of energy balance in animals. These pathways are also relevant to human energy homeostasis, as mutations in key genes are correlated with obesity. Many of the genes identified mediate the effects of leptin, and are therefore primarily involved in sensing and responding to peripheral signals. In seasonal animals, such as the Siberian hamster (Phodopus sungorus), there is evidence for a higher level of regulation. The systems involved regulate body weight around an apparent 'set-point' through the action of photoperiod via the neurohormone, melatonin. The ability to manipulate energy balance through photoperiod (and melatonin) in the seasonal-animal model offers novel opportunities to identify further fundamental aspects of the control mechanisms involved in the central control of energy homeostasis and body weight.
\end{abstract}

Energy balance: Melatonin: Hypothalamus: Gene expression

Every schoolchild learns about the conservation of energy, which is the basis of the first law of thermodynamics. Unfortunately, when it comes to nutrition most individuals would like to conveniently deny its existence. Nevertheless, the principle that energy can neither be created nor destroyed, rather it can only be converted into another form, is the fundamental basis of obesity. Obesity is now a major problem, and for an afflicted individual it results when the intake of energy in the form of food exceeds the energy dissipated through either metabolism or exercise. As a result the surplus energy is converted into triacylglycerols, and is stored within adipocytes. What drives us to consume more food and take in more energy than we can dissipate either through metabolism or exercise is still not understood. Some researchers would argue that the evolutionary advantage to resist body-weight gain is weak, relative to that for energy deficit. Thus, while we find it hard to lose weight through dieting due to a strong resistance to energy deficit, by contrast we seemingly defend against energy surplus only weakly. Despite this assertion some researchers argue that as human body weights are seemingly stable over considerable periods of time, this factor suggests that there are mechanisms that contribute to long-term energy-balance regulation in human subjects (Rosenbaum et al. 1997).
However, other researchers argue that the stability in body weight of human subjects reflects the average of the population, and this argument ignores the substantial fluctuations which occur on an individual basis (Garrow, 1999). Nevertheless, there is a powerful evidence for the regulation of energy balance and body weight in animals (Levin \& Keesey, 1998; Mercer, 1998; Mercer et al. 2000a). While there are many physiological and biochemical mechanisms and systems involved in the regulation of food intake and energy balance, the hypothalamus is recognised as an important neural integrative centre in the brain (Kalra et al. 1999). The present review focuses on the seasonalanimal model, and the Siberian hamster (Phodopus sungorus) primarily, to explore what lessons can be learned from this extraordinary animal in terms of energy homeostasis and body-weight regulation, particularly in relation to hypothalamic systems.

\section{Regulation involving the hypothalamus}

The importance of the hypothalamus to the regulation of food intake and energy balance was first recognised in the 1940 s and 1950 s, when it was revealed that discrete lesions to specific nuclei within the hypothalamus, including the

\footnotetext{
Abbreviations: AgRP, Agouti-related protein; ARC, arcuate nucleus; LD, long day; LH, lateral hypothalamus; MC, melanocortin; MCH, melaninconcentrating hormone; NPY, neuropeptide Y; POMC, pro-opiomelanocortin; PVN, paraventricular nucleus; SD, short day.

*Corresponding author: Professor Peter J. Morgan, fax +44 1224 716698, email p.morgan@ rri.sari.ac.uk
} 
ventromedial nucleus, dorsomedial nucleus, paraventricular nucleus (PVN) and the lateral hypothalamus (LH), severely disturbed ingestive behaviour (Kalra et al. 1999). While lesions to the LH promoted hypophagia and reduced body weight, lesions to the other sites caused hyperphagia and increased body weight. From this finding emerged the concept of hunger and satiety centres (Stellar, 1954). Relatively-recent studies have led to a more detailed understanding of some of the neural substrates of these behaviours, and have revealed a complex interactive neural network. Key to the development of this understanding has been the elucidation of the molecular basis of obesity in a number of genetic mouse models, including the $o b / o b$ (Zhang et al. 1994), db/db (Chen et al. 1996) and Agouti (A $\left.{ }^{y}\right)$ (Miller et al. 1993; Cone et al. 1996a,b) strains together with creation of transgenic mice with targeted gene deletions (Erickson et al. 1996a,b; Huszar et al. 1997; Shimada et al. 1998; Chemelli et al. 1999). From these studies it has become clear that neural pathways contributing both orexigenic and anorexigenic drives can be distinguished (see Fig. 1).

In addition to the hypothalamic sites mentioned earlier, the importance of the arcuate nucleus (ARC) to the hypothalamic integration of energy balance has been recognised (Kalra et al. 1999). The ARC is located at the base of the hypothalamus and extends rostrocaudally from the optic chiasm to the mammillary bodies. It is an important hypothalamic nucleus, as it is the site of synthesis of both orexigenic peptides, including neuropeptide Y (NPY), Agouti-related protein (AgRP), galanin and $\beta$-endorphin, and the anorexigenic peptides, $\alpha$-melanocyte-stimulating hormone and cocaine- and amphetamine-related peptide

(a)

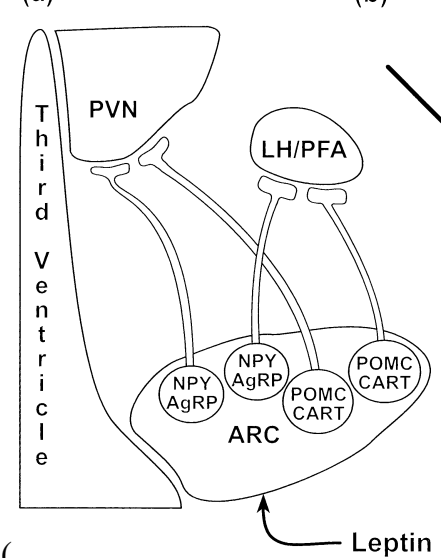

Fig. 1. (a) Orexigenic neuropeptide $Y$ (NPY) and agouri-related protein (AgRP) and anorexigenic (pro-opiomelanocortin (POMC) and cocaine- and amphetamine-related peptide (CART)) neurones project from the (arcuate nucleus) ARC to the (paraventricular nucleus) PVN and the lateral hypothalamus $(\mathrm{LH})$ - perifornical areas (PFA) of the hypothalamus. Leptin input occurs through receptors in the ARC. (b) NPY stimulates orexigenic activity through NPY receptors (NPY R), whereas $\alpha$-melanocyte-stimulating hormone (MSH) stimulates anorexigenic activity through the melanocortin 4 receptor (MC4 $\mathrm{R}$ ) in the PVN. The orexigenic activity of AgRP occurs by blocking the activity of MSH at the MC4 R. Leptin acts to inhibit the orexigenic pathway but stimulate the anorexigenic pathway.
(Kalra et al. 1999). Interestingly, the two most potent orexigenic peptides, NPY and AgRP, are co-expressed in the same subset of neurons (Broberger et al. 1998; Hahn et al. 1998), and similarly, pro-opiomelanocortin (POMC), the precursor for the anorexigenic peptide $\alpha$-melanocytestimulating hormone, and the orexigenic peptide, $\beta$-endorphin, are co-localised with cocaine- and amphetamine-related peptide within a different subset of neurons of the ARC (Elias et al. 1998). These orexigenic and anorexigenic neurons project to various hypothalamic sites with terminal fields in the ventromedial nucleus, dorsomedial nucleus, PVN and the $\mathrm{LH}$, where microinjection of these different peptides have been shown to modulate ingestive behaviour (Kalra et al. 1999).

A major function of the ARC is in the primary integration of peripheral nutritional signals, such as leptin and insulin (Schwartz et al. 2000). It is particularly well disposed to this role due to the absence of a blood-brain barrier, allowing direct access to humoral signals. Receptors for both leptin and insulin have been localised to the ARC, and leptin receptor $(\mathrm{OB}-\mathrm{Rb})$ mRNA is known to be expressed within both NPY-AgRP (Mercer et al. 1996; Broberger et al. 1998) and POMC-cocaine- and amphetamine-related peptide neurons (Cheung et al. 1997; Elias et al. 1998) indicating a direct action of leptin on both these orexigenic and anorexigenic pathways.

\section{The anorexigenic melanocortin pathway}

As mentioned earlier, spontaneous-mutant and geneknockout mouse models have contributed substantially to our current understanding of the neural basis of ingestive behaviour. From such studies has emerged the critical role of the melanocortin (MC) receptor 4. Targeted disruption of the MC4 receptor gene resulted in a maturity-onset obese phenotype, implicating this receptor in the restraint of feeding behaviour (Huszar et al. 1997). In support of this implication it was shown that a synthetic agonist of the MC4 receptor, MTII, suppressed food intake when administered intracerebroventricularly to hyperphagic rats, and this response could be blocked by an antagonist of these receptors, SHU9119 (Fan et al. 1997). Further support for the importance of the MC receptors came from studies of the

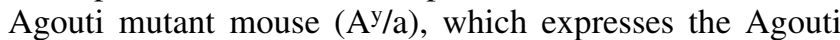
protein ectopically (Cone et al. 1996a,b). In the wild-type mouse, Agouti protein expression is restricted to the dermis, where it acts as a natural antagonist of the $\mathrm{MC} 1$ receptors and contributes to the regulation of coat colour (Cone et al. $1996 a, b)$. Agouti also functions as an antagonist of the MC4 receptor, so when ectopically expressed in the $\mathrm{A}^{\mathrm{y} / \mathrm{a}}$ mutant mouse, it blocks MC4 receptors in the brain to produce an obese phenotype (Cone et al. 1996a,b). Subsequently AgRP, a peptide with homology with Agouti, has been identified (Shutter et al. 1997). This peptide is a functional antagonist of the MC3 and MC4 receptors (Ollmann et al. 1997), and is expressed within the hypothalamus, where it is co-expressed with NPY within the ARC. Both overexpression of AgRP and intracerebroventricular administration results in hyperphagia (Shutter et al. 1997; Rossi et al. 1998), consistent with its role as an orexigenic signal. The mRNA for MC4 receptors is 
widespread throughout the brain, but sites of expression include the PVN, ventromedial nucleus and dorsomedial nucleus of the hypothalamus (Mountjoy et al. 1994). Currently, most attention is focused on the role and function of MC4 receptors within the PVN. Through differential activity on the POMC and AgRP neurons within the ARC, it is possible to conceive how leptin could modulate ingestive behaviour involving the activity of MC4 receptors at this site (see Fig. 1(b)).

\section{Orexigenic pathways}

NPY remains the most extensively studied orexigenic peptide, and there is compelling evidence to support its physiological role in the regulation of food intake and energy expenditure (Stanley et al. 1986; Kalra et al. 1999). It was somewhat surprising, therefore, that targeted deletion of this gene did not manifest an altered phenotype (Erickson et al. 1996b), unless expressed on an ob/ob background, when a less-obese phenotype was produced (Erickson et al. $1996 a$ ). Compensatory signalling has been used to explain this lack of effect. A potential explanation may be the ability of AgRP to provide a robust orexigenic signal in the absence of NPY (Cowley et al. 1999). Alternatively, there are other orexigenic peptides that could fulfil this role. Melaninconcentrating hormone $(\mathrm{MCH})$ is a nineteen amino acid peptide that is produced within the zona incerta and LH, and several lines of evidence support its role as an orexigenic peptide ( $\mathrm{Qu}$ et al. 1996). First, $\mathrm{MCH}$ has been shown to stimulate feeding (Qu et al. 1996), although its activity relative to NPY appears less potent and of shorter duration (Kalra et al. 1999). Second, expression of MCH mRNA is increased in response to energy restriction and leptin deficiency (Qu et al. 1996). Third, and perhaps most compelling, MCH knockout mice have reduced food intake and an exceptionally-lean phenotype relative to wild-type control mice (Shimada et al. 1998). The recent identification of the $\mathrm{MCH}$ receptor will undoubtedly be important for the clarification of its role in the regulation of ingestive behaviour.

Two other peptides produced in the LH, perifornical area and the zona incerta are the orexins $\mathrm{A}$ and $\mathrm{B}$, also known as hypocretins 1 and 2 (Sakurai et al. 1998; de Lecea et al. 1998). While these peptides have been shown to increase food intake when administered centrally into rats, they also induce arousal behaviour (de Lecea et al. 1998; Sakurai et al. 1998). Furthermore, mice with targeted deletion of the orexin gene display narcoleptic behaviour (Chemelli et al. 1999), which is characterised by sudden bouts of sleep outwith the normal sleep-wake cycle. These results question whether the orexigenic activity of these peptides is their primary function, or a secondary consequence from their effects on arousal behaviour.

\section{Compensatory (peripheral feedback) $v$. regulatory (central) pathways in body-weight control}

At present much of our knowledge about the central mechanisms of body-weight control has been driven by understanding the mechanisms used by the animal to sense and respond to nutritional signals, primarily leptin. These mechanisms can be considered as compensatory pathways involving hypothalamic integration of peripheral signals of energetic and nutrient status (Mercer et al. 2000a). There is clearly much yet to understand, particularly in relation to the differential regulation of the myriad of signals involved in the process of ingestive behaviour. Nevertheless, evidence from studies of seasonal animals indicates that there are 'higher levels' of regulation involved in energy balance, which are independent of nutritional feedback, and which probably serve ultimately to set the level of sensitivity of response to the compensatory pathways, and thereby define the level at which body weight is defended.

\section{The seasonal Siberian hamster model}

Seasonal mammals have evolved different strategies to survive the metabolic challenges of overwintering. The Siberian hamster adopts the seemingly counter-intuitive strategy of reducing its body fat reserves before the onset of winter. While this strategy undoubtedly reduces the animal's insulation, it nonetheless reduces the animal's energy (food) requirements over the winter period. The reduction in body weight is regulated by photoperiod (Mercer et al. 2000a; see Fig. 2(a)). Under continuous 'summer' conditions (long photoperiod), body weight remains stable. If the animal perceives a shortening of photoperiod towards winter conditions, either as a gradual change (natural conditions) or as an abrupt change (laboratory conditions), then it progressively loses body weight. Over an 18-week period under these conditions the Siberian hamster can lose between 30 and $40 \%$ of its initial body weight, mainly as fat (Mercer et al. 2000b,c). These changes provoke a number of fundamental questions.

First, as the decline in body weight occurs, there is an accompanying loss in body fat. Associated with this process is a decreased level of leptin gene expression in fat (Klingenspor et al. 1996; Mercer et al. 2000b,c), and lowered plasma leptin levels (Klingenspor et al. 2000). Similar reductions in leptin levels in rats or mice through cold exposure or food restriction would elicit compensatory hyperphagic responses to defend against the perceived energy deficit (Hardie et al. 1996; Mercer et al. 1997; Schwartz et al. 1997, 1998; Thornton et al. 1997). Clearly, this process does not occur, as the hamster continues to lose weight. Thus, this situation implies that in the Siberian hamster during photoperiodic-induced loss of body weight, the animal overrides any orexigenic signal coming from leptin. Second, what is the activity of hypothalamic neuropeptide systems within the brain during a body-weight cycle?

To address these questions, the expression of mRNA for many of the neuropeptides thought to be involved in the hypothalamic regulation of energy balance has been studied at different stages of the body-weight cycle of the Siberian hamster (Reddy et al. 1999; Mercer et al. 2000b,c). For comparison, the influence of short-term food deprivation on hypothalamic gene expression has been examined. Measured after 18 weeks of long days (LD) and short days (SD), food deprivation for $24 \mathrm{~h}$ caused gene expression of the orexigenic peptides NPY and AgRP to increase, consistent with a greater anabolic drive. Similar effects of 
(a)

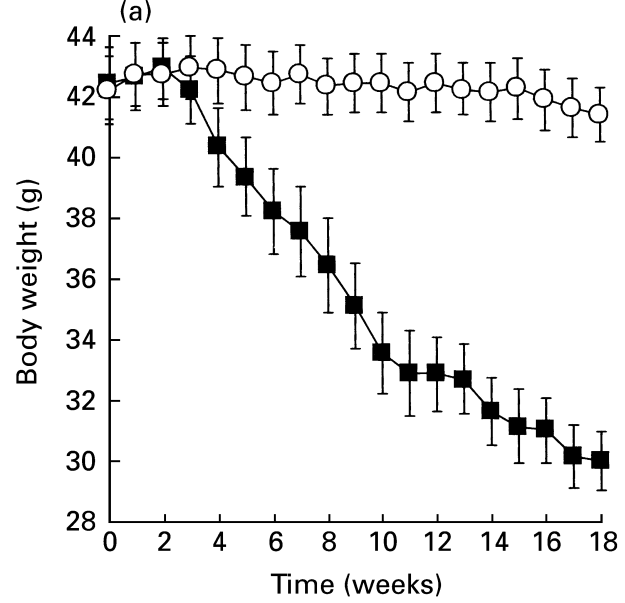

(b)

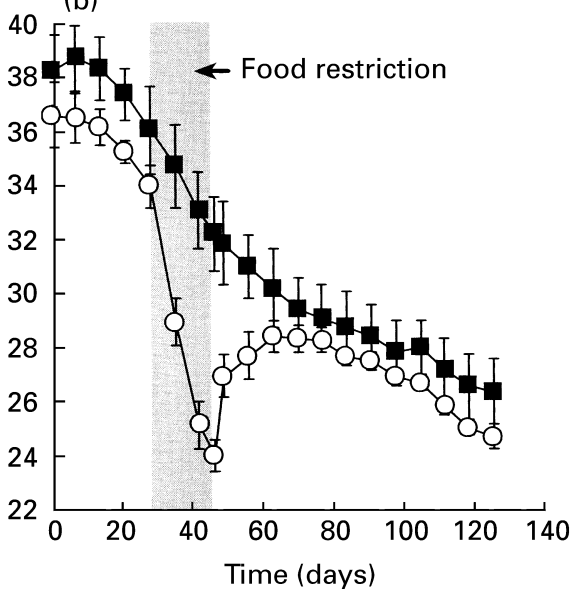

Fig. 2. (a) Effects of photoperiod on the body weight of the Siberian hamster (Phodopus sungorus). Under long days ( $16 \mathrm{~h}$ light $-8 \mathrm{~h}$ dark; $O$; $L D$ ) body weight remains stable, whereas short days ( $8 \mathrm{~h}$ light $-16 \mathrm{~h}$ dark; $\mathbf{\square}$; SD) promotes loss of body weight. (b) Superimposition of food restriction on the loss of body weight by SD reduces the body weight further. Return to ad libitum feeding restores body weight to a position set by the time under SD.

food deprivation on the expression of hypothalamic NPY gene expression have been observed after 12 weeks of photoperiodic treatment. These changes may be driven by lowered levels of leptin associated with food deprivation, and predicted by the lowered levels of leptin gene expression in adipose tissue. By contrast, gene expression of the orexigenic peptides $\mathrm{MCH}$ and orexin and the anorexigenic peptide corticotrophin-releasing factor was unaltered by food deprivation. A reduction in POMC gene expression during food deprivation in LD was limited in magnitude and restricted to a subdivision of the ARC. Overall, these data are consistent with those from other rodent models, which suggests that NPY in conjunction with co-expressed AgRP provide a powerful orexigenic drive, which may be augmented by reductions in the activity of anorexigenic systems. NPY is known to be a potent orexigenic peptide when administered intracerebroventricularly into Siberian hamsters (Boss-Williams \& Bartness, 1996), as in other rodent species (Stanley et al. 1986; Kalra et al. 1999). Currently, there is no data on the effects of AgRP- or POMC-processing products in this species.

When hamsters have been held under SD for 18 weeks the levels of plasma leptin are low, inferred from the level of leptin gene expression in adipose tissue. Recent data have confirmed that plasma levels are low following both 9.5 and 16.5 weeks of SD in this species relative to LD control animals (Klingenspor et al. 2000). Under such conditions it might be predicted that the status of hypothalamic gene expression would reflect that of a food-deprived hamster. In part this is the case. There is a raised level of gene expression for the orexigenic peptide AgRP after 18 weeks of $\mathrm{SD}$, and reduced gene expression for the peptide precursor POMC after both 12 and 18 weeks of SD. Both these changes are consistent with a net increased anabolic drive. By contrast with the food-deprivation paradigm, the gene expression for NPY was unchanged after 12 and 18 weeks of SD, and therefore this differential effect relative to AgRP, which is co-expressed with NPY, suggests differ- ential regulation of the two transcripts. However, a reduced level of NPY gene expression has been observed after 8 weeks of SD. While this finding would be consistent with a reduced anabolic drive at this earlier time point in the body-weight cycle, there was no associated change in the level of POMC gene expression, which might provide a complementary increase in catabolic drive. Thus, after 12 and 18 weeks of SD, in general terms the gene expression changes appear to reflect the reduction in circulating leptin levels in adult male Siberian hamsters.

There is a danger, however, of placing too much emphasis on changes in the level of gene expression as an index of hypothalamic neural activity. Injection of leptin intraperitoneally into Siberian hamsters after 8 weeks of either LD or SD had no effect on hypothalamic expression of the NPY, POMC and orexin genes (Reddy et al. 1999). Nevertheless, under the same conditions leptin was shown to have clear inhibitory effects on food intake over a $6 \mathrm{~h}$ period (Reddy et al. 1999). Similarly, it has been shown that injection of Siberian hamsters with leptin under both LD and SD conditions leads to a decrease in body weight (Mercer et al. 2000a). Thus, it is possible that leptin may influence neuronal activities of the NPY and POMC neurons through altered synthesis of the protein without any accompanying change in gene expression. Overall, the data from geneexpression studies provide poor evidence that the currentlyknown hypothalamic orexigenic and anorexigenic pathways are involved in driving the catabolic changes induced by photoperiod, as opposed to reflecting the extant catabolic state. More information on the expression and activity of the peptides is required.

The primary role of the ARC appears to be to integrate and transmit nutritional feedback information, and the geneexpression studies described earlier reflect this function in general terms. Using monosodium glutamate lesions it has been shown that the photoperiodic-induced regulation of body weight is seemingly unaffected when $80 \%$ of the ARC neurons are destroyed (Ebling et al. 1998). Hamsters with 
monosodium glutamate lesions show a slower rate of weight gain relative to sham controls, although both groups eventually achieve the same asymptotic body weight. When transferred to SD at 8 weeks of age the monosodium glutamate-lesioned animals showed a reduction in body weight in response to photoperiod, reaching a similar body weight nadir to that of sham-lesioned controls (Ebling et al. 1998). While it is possible that the $20 \%$ of the ARC neurons spared by the monosodium glutamate lesion could compensate for the loss of the majority of ARC neurons, this evidence, together with the foregoing arguments, implies that the ARC may not be required to mediate the photoperiod-induced reduction in body weight. Although the effect of photoperiod on the encoding of a seasonallyappropriate body weight may be largely independent of the ARC, it is unlikely that this 'target' body weight will be achieved without peripheral feedback signals conveying accurate information about body composition and energy status.

\section{Evidence for body-weight regulation around a 'set-point'}

The view that photoperiod alters a central control mechanism, which is independent of peripheral inputs, at least in terms of the encoding of a 'target' body mass, is reinforced by two classic experiments. The first experiment demonstrated the phenomenon of a 'sliding set-point' in the Siberian hamster (Steinlechner et al. 1983). In this experiment Siberian hamsters were maintained in ambient photoperiod during the transition from summer to winter, during which time the animals lost body weight as part of their natural body-weight cycle. At two periods during the body-weight cycle food restriction was imposed, which accelerated the loss of body weight. Remarkably, when the animals were returned to ad libitum feeding, on each occasion the hamsters re-gained weight, but only to the point 'set' by the appropriate temporal position in the bodyweight cycle. Thus, the study suggests that the animals use photoperiod to continually and progressively re-adjust the position where body weight is defended. Recently, our group has replicated this experiment using an abrupt transition from $\mathrm{LD}$ to $\mathrm{SD}$, rather than the change in natural photoperiod used in the original experiment (see Fig. 2(b)). These studies under artificial photoperiod support and extend the hypothesis that photoperiod programmes a temporal change in body-weight 'set-point'.

The second of the classic experiments involves the re-gain of body weight following the transition from SD to LD in hamsters at their body-weight nadir. Siberian hamsters were clamped at the level of food intake sufficient to maintain their body weight under SD, i.e. the level previously consumed voluntarily, and were then transferred to LD (Masuda \& Oishi, 1995). This change in photoperiod stimulated increased food intake and body weight in control animals. In the clamped animals, unable to increase their food intake, it resulted in a breakdown in their circadian activity cycles, as the animals scurried around furiously seeking food. This behavioural change superimposed on the food restriction ultimately led to death. In the light of these findings this experiment can be interpreted as the photoperiod re-setting the 'set-point' for body weight to a new higher level; the animal then perceives its body weight to be inappropriately low, which in turn stimulates foodseeking behaviours designed to increased food intake. As intake fails to match both the level required for growth and that required to meet the energetic demands of the increased locomotor activity, the animals exhaust themselves. This dramatic experiment reinforces the concept of photoperiod altering a 'set-point' for body weight, independently of any change in nutritional inputs, leading to the hypothesis that photoperiod alters specific neural circuits in the brain that alter the balance of food intake and energy expenditure. While we refer to an altered 'set-point' for body weight, we do so advisedly, and do not wish to imply that this is a 'hard wired' set-point, rather an alteration in a neural equilibrium which contributes to the regulation of energy balance.

\section{The role of melatonin}

Up to this point we have referred to the regulation of bodyweight 'set point' by photoperiod. However, it is known that photoperiod is transduced into a hormonal signal, melatonin, within the pineal gland. Melatonin is produced as a characteristic diurnal pattern, so that photoperiod is encoded as a durational signal by the length of the nocturnal secretion of melatonin (Morgan et al. 1994). During the daylight hours plasma melatonin levels are low, due to the suppressive influence of light on melatonin production by the pineal gland. At night plasma melatonin levels rise dramatically, and remain high for a period directly related to the length of the night. Thus, during the LD and short nights of summer, the nocturnal melatonin signal is short, whereas during the SD and long nights of winter the nocturnal melatonin signal is long. Recent experiments in our laboratory have shown that at the level of the pituitary (pars tuberalis), the duration of the melatonin signal is transposed into the amplitude of early-response gene expression, so that short melatonin signals (winter) promote higher levels of gene expression than long melatonin signals (summer; Morgan et al. 1998; Messager et al. 1999).

The target sites through which melatonin regulates seasonal body weight are not yet clarified, although two primary candidate sites within the hypothalamus have been identified through receptor in vitro autoradiography (Morgan et al. 1994; C Ellis, J Mercer and PJ Morgan, unpublished results). These two sites are the suprachiasmatic nucleus and the dorsomedial nucleus. Both these sites project afferents to the PVN, which is an important integrative site for energy balance regulation. Nothing is known of the neural substrates that may mediate the photoperiod-melatonin-regulated changes in food intake and body weight, but because of its fundamental importance to the balance of food intake and body weight in the seasonal animal, dissecting its molecular and neural basis offers great potential to advance our fundamental understanding of energy regulation at a central level. A hypothetical model of how melatonin may influence hypothalamic energy balance mechanisms relative to the compensatory signals such as leptin is shown in Fig. 3. Our present focus is to identify the genes which provide the neural basis of the 'sliding set-point' regulation of body weight in the Siberian hamster. This goal is long-term, 


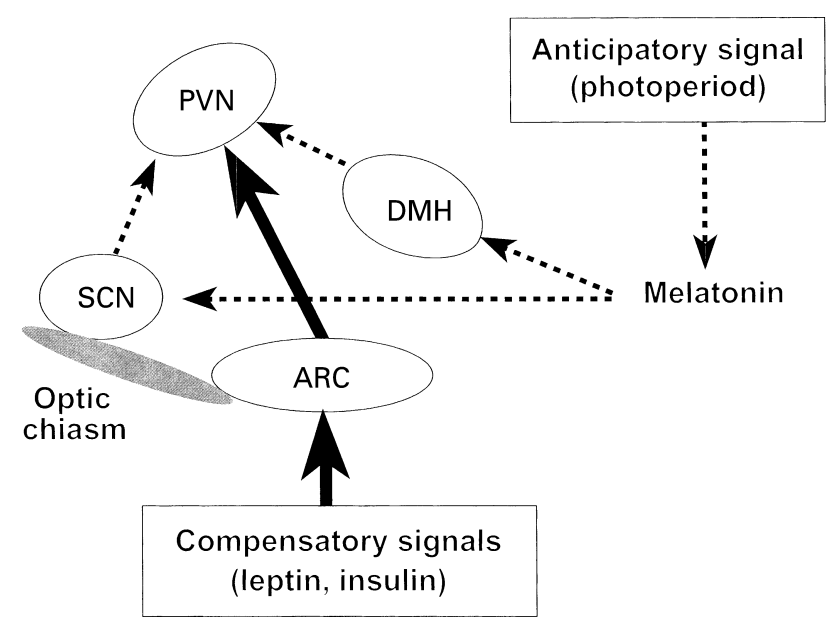

Fig. 3. Distinction between pathways involved in compensatory and anticipatory regulation of body weight. Compensatory signals such as leptin act via the arcuate nucleus (ARC) through neurones that project to the paraventricular nucleus (PVN); see Fig. 1). Photoperiod acts through melatonin and its receptors in the dorsomedial nucleus $(\mathrm{DMH})$ and the suprachiasmatic nucleus $(\mathrm{SCN})$, from where there are projections to the PVN.

involving subtractive hybridisation and cDNA microarray technologies.

\section{Perspective for human obesity}

An obvious question is whether the identification of genes from a seasonal animal species will have any relevance to human physiology. The straightforward response to this challenge is that it is uncertain. While human subjects are susceptible to changes in the light-dark cycle, they show no overt seasonal changes in physiology in response to photoperiod. Thus, there is no rationale for manipulating human body weight through either photoperiod or melatonin. It can be argued that human subjects do not appear to tightly regulate body weight around a given 'set-point', otherwise obesity would not be a problem. However, this position represents an oversimplification, and it would be incorrect to conclude that human subjects do not have neural mechanisms involved in energy homeostasis. Evidence for the possibility of neural mechanisms has been the identification of mutations in the MC4 receptor, leptin receptor and the POMC-processing enzymes, and their association with obese phenotypes in human subjects (Jackson et al. 1997; Montague et al. 1997; Vaisse et al. 1998; Yeo et al. 1998). These examples highlight how genes and their protein products that have been identified as important in the regulation of energy balance in animal models are also important in human subjects. However, in human subjects other factors impinge on the regulation of food intake; these factors include psycho-social influences and the ready availability of energy-dense convenience diets (Mela et al. 1999; Wardle, 1999). Such malleability of the appetite regulatory system is not peculiar to human subjects, as in the laboratory environment some strains of rat fed energy-dense diets gain excess weight over chow-fed controls (so-called diet-induced obesity; Levin \& Keesey,
1998). Furthermore, in out-bred Sprague-Dawley rats, it has been shown that differential susceptibilities to diet-induced obesity can be discerned (Levin \& Keesey, 1998, Levin \& Dunn-Meynell, 2000). Some rats are prone to diet-induced obesity, whereas other rats are diet-induced-obesity resistant. Nevertheless, even the latter group can be forced to become obese if provided with a superenergetic diet. Interestingly, however, these rats return to their pre-obese body weight when returned to a euenergetic chow diet. This finding contrasts with that for the diet-induced-obesityprone rats, which maintain their higher body weight even after they return to a euenergetic chow diet. These data suggest that diet-induced-obesity-resistant rats regulate body weight around a set-point, but in the face of a superenergetic diet this set-point can be exceeded. By contrast, in the diet-induced-obesity-prone rats the high-energy diet alters the set-point to a new and higher level. It is interesting to consider whether this differential susceptibility to dietinduced obesity reflects the differential propensity to obesity observed in the human population. This being the case, understanding the mechanisms that contribute to the body-weight set-point is an important goal, and the Siberian hamster is therefore a potentially powerful model through which to identify the mechanisms.

\section{Acknowledgements}

The authors would like to acknowledge the financial support of the Scottish Executive Rural Affairs Department.

\section{References}

Boss-Williams KA \& Bartness TJ (1996) NPY stimulation of food intake in Siberian hamsters is not photoperiod dependent. Physiology and Behavior 59, 157-164.

Broberger C, Johansen J, Johansson C, Schalling M \& Hokfelt T (1998) The neuropeptide Y/agouti gene-related protein (AGRP) brain circuitry in normal, anorectic, and monosodium glutamatetreated mice. Proceedings of the National Academy of Sciences USA 95, 15043-15048.

Chemelli RM, Willie JT, Sinton CM, Elmquist JK, Scammell T, Lee C, Richardson JA, Williams SC, Xiong Y, Kisanuki Y, Fitch TE, Nakazato M, Hammer RE, Saper CB \& Yanagisawa M (1999) Narcolepsy in orexin knockout mice: molecular genetics of sleep regulation. Cell 98, 437-451.

Chen H, Charlat O, Tartaglia LA, Woolf EA, Weng X, Ellis SJ, Lakey ND, Culpepper J, Moore KJ, Breitbart RE, Duyk GM, Tepper RI \& Morgenstern JP (1996) Evidence that the diabetes gene encodes the leptin receptor: identification of a mutation in the leptin receptor gene in $\mathrm{db} / \mathrm{db}$ mice. Cell 84, 491-495.

Cheung CC, Clifton DK \& Steiner RA (1997) Proopiomelanocortin neurons are direct targets for leptin in the hypothalamus. Endocrinology 138, 4489-4492.

Cone RD, Lu D, Koppula S, Vage DI, Klungland H, Boston B, Chen W, Orth DN, Pouton C \& Kesterson RA (1996a) The melanocortin receptors: agonists, antagonists, and the hormonal control of pigmentation. Recent Progress in Hormone Research 51, 287-317.

Cone RD, Lu D, Koppula S, Vage DI, Klungland H, Boston B, Chen W, Orth DN, Poulton C \& Kesterson RA (1996b) The melanocortin receptors: agonists, antagonists, and hormonal control of pigmentation. Discussion. Recent Progress in Hormone Research 51, 318. 
Cowley MA, Pronchuk N, Fan W, Dinulescu DM, Colmers WF \& Cone RD (1999) Integration of NPY, AGRP, and melanocortin signals in the hypothalamic paraventricular nucleus: evidence of a cellular basis for the adipostat. Neuron 24, 155-163.

de Lecea L, Kilduff TS, Peyron C, Gao X, Foye PE, Danielson PE, Fukuhara C, Battenberg EL, Gautvik VT, Bartlett FS II, Frankel WN, van den Pol AN, Bloom FE, Gautvik KM \& Sutcliffe JG (1998) The hypocretins: hypothalamus-specific peptides with neuroexcitatory activity. Proceedings of the National Academy of Sciences USA 95, 322-327.

Ebling FJ, Arthurs OJ, Turney BW \& Cronin AS (1998) Seasonal neuroendocrine rhythms in the male Siberian hamster persist after monosodium glutamate-induced lesions of the arcuate nucleus in the neonatal period. Journal of Neuroendocrinology 10, 701-712.

Elias CF, Lee C, Kelly J, Aschkenasi C, Ahima RS, Couceyro PR, Kuhar MJ, Saper CB \& Elmquist JK (1998) Leptin activates hypothalamic CART neurons projecting to the spinal cord. Neuron 21, 1375-1385.

Erickson JC, Clegg KE \& Palmiter RD (1996a) Sensitivity to leptin and susceptibility to seizures of mice lacking neuropeptide Y. Nature 381, 415-421.

Erickson JC, Hollopeter G \& Palmiter RD (1996b) Attenuation of the obesity syndrome of ob/ob mice by the loss of neuropeptide Y. Science 274, 1704-1707.

Fan W, Boston BA, Kesterson RA, Hruby VJ \& Cone RD (1997) Role of melanocortinergic neurons in feeding and the agouti obesity syndrome. Nature $\mathbf{3 8 5}, 165-168$.

Garrow J (1999) Significance of within person weight variation. Obesity. British Nutrition Foundation Report, pp. 132-138. Oxford: Blackwell Science.

Hahn TM, Breininger JF, Baskin DG \& Schwartz MW (1998) Coexpression of Agrp and NPY in fasting-activated hypothalamic neurons. Nature Neuroscience 1, 271-272.

Hardie LJ, Rayner DV, Holmes S \& Trayhurn P (1996) Circulating leptin levels are modulated by fasting, cold exposure and insulin administration in lean but not Zucker (fa/fa) rats as measured by ELISA. Biochemical and Biophysical Research Communications 223, 660-665.

Huszar D, Lynch CA, Fairchild-Huntress V, Dunmore JH, Fang Q, Berkemeier LR, Gu W, Kesterson RA, Boston BA, Cone RD, Smith FJ, Campfield LA, Burn P \& Lee F (1997) Targeted disruption of the melanocortin-4 receptor results in obesity in mice. Cell 88, 131-141.

Jackson RS, Creemers JW, Ohagi S, Raffin-Sanson ML, Sanders L, Montague CT, Hutton JC \& O'Rahilly S (1997) Obesity and impaired prohormone processing associated with mutations in the human prohomone convertase 1 gene. Nature Genetics 16, 303-306.

Kalra SP, Dube MG, Pu S, Xu B, Horvath TL \& Kalra PS (1999) Interacting appetite-regulating pathways in the hypothalamic regulation of body weight. Endocrine Reviews 20, 68-100.

Klingenspor M, Dickopp A, Heldmaier G \& Klaus S (1996) Short photoperiod reduces leptin gene expression in white and brown adipose tissue of Djungarian hamsters. FEBS Letters 399, 290-294.

Klingenspor M, Niggemann H \& Heldmaier G (2000) Modulation of leptin sensitivity by short photoperiod acclimation in the Djungarian hamster, Phodopus sungorus. Journal of Comparative Physiology 170B, 37-43.

Levin BE \& Dunn-Meynell AA (2000) Defense of body weight against chronic caloric restriction in obesity-prone and -resistant rats. American Journal of Physiology 278, R231-R237.

Levin BE \& Keesey RE (1998) Defense of differing body weight set points in diet-induced obese and resistant rats. American Journal of Physiology 274, R412-R419.
Masuda A \& Oishi T (1995) Effects of restricted feeding on the light-induced body weight change and locomotor activity in the Djungarian hamster. Physiology and Behavior 58, 153-159.

Mela D, Ritson C \& Kuznesof S (1999) Aetiology of obesity X: Food policy and eating patterns. Obesity. British Nutrition Foundation Report, pp. 101-115. Oxford: Blackwell Science.

Mercer JG (1998) Regulation of appetite and body weight in seasonal mammals. Comparative Biochemistry and Physiology 119C, 295-303.

Mercer JG, Adam CL \& Morgan PJ (2000a) Towards an understanding of physiological body mass regulation: seasonal animal models. Nutritional Neuroscience 3, 307-320.

Mercer JG, Hoggard N, Williams LM, Lawrence CB, Hannah LT, Morgan PJ \& Trayhurn P (1996) Coexpression of leptin receptor and preproneuropeptide Y mRNA in arcuate nucleus of mouse hypothalamus. Journal of Neuroendocrinology 8, 733-735.

Mercer JG, Moar KM, Rayner DV, Trayhurn P \& Hoggard N (1997) Regulation of leptin receptor and NPY gene expression in hypothalamus of leptin-treated obese $(\mathrm{ob} / \mathrm{ob})$ and cold-exposed lean mice. FEBS Letters 402, 185-188.

Mercer JG, Moar KM, Ross AW, Hoggard N \& Morgan PJ (2000b) Photoperiod regulates arcuate nucleus POMC, AGRP, and leptin receptor mRNA in Siberian hamster hypothalamus. American Journal of Physiology 278, R271-R281.

Mercer JG, Moar KM, Ross AW \& Morgan PJ (2000c) Regulation of leptin receptor, POMC and AGRP gene expression by photoperiod and food deprivation in the hypothalamic arcuate nucleus of the male Siberian hamster (Phodopus sungorus). Appetite 34, 109-111.

Messager S, Ross AW, Barren P \& Morgan PJ (1999) Decoding photoperiodic time through Perl and ICER gene amplitude. Proceedings of the National Academy of Sciences USA 96, 9938-9943.

Miller MW, Duhl DM, Vrieling H, Cordes SP, Ollmann MM, Winkes BM \& Barsh GS (1993) Cloning of the mouse agouti gene predicts a secreted protein ubiquitously expressed in mice carrying the lethal yellow mutation. Genes and Development $\mathbf{7}$, 454-467.

Montague CT, Farooqi IS, Whitehead JP, Soos MA, Rau H, Wareham NJ, Sewter CP, Digby JE, Mohammed SN, Hurst JA, Cheetham CH, Earley AR, Barnett AH, Prins JB \& O'Rahilly S (1997) Congenital leptin deficiency is associated with earlyonset obesity in humans. Nature 387, 903-908.

Morgan PJ, Barrett P, Howell HE \& Helliwell R (1994) Melatonin receptors: localization, molecular pharmacology and physiological significance. Neurochemistry International 24, 101-146.

Morgan PJ, Ross AW, Graham ES, Adam C, Messager S \& Barrett P (1998) oPerl is an early response gene under photoperiodic regulation in the ovine pars tuberalis. Journal of Neuroendocrinology 10, 319-323.

Mountjoy KG, Mortrud MT, Low MJ, Simerly RB \& Cone RD (1994) Localization of the melanocortin-4 receptor (MC4-R) in neuroendocrine and autonomic control circuits in the brain. Molecular Endocrinology 8, 1298-1308.

Ollmann MM, Wilson BD, Yang YK, Kerns JA, Chen Y, Gantz I \& Barsh GS (1997) Antagonism of central melanocortin receptors in vitro and in vivo by agouti-related protein. Science 278, 135-138.

Qu D, Ludwig DS, Gammeltoft S, Piper M, Pelleymounter MA, Cullen MJ, Mathes WF, Przypek R, Kanarek R \& Maratos-Flier $\mathrm{E}$ (1996) A role for melanin-concentrating hormone in the central regulation of feeding behaviour. Nature 380, 243-247.

Reddy AB, Cronin AS, Ford H \& Ebling FJ (1999) Seasonal regulation of food intake and body weight in the male Siberian hamster: studies of hypothalamic orexin (hypocretin), 
neuropeptide Y (NPY) and pro-opiomelanocortin (POMC). European Journal of Neuroscience 11, 3255-3264.

Rosenbaum M, Leibel RL \& Hirsch J (1997) Obesity. New England Journal of Medicine 337, 396-407.

Rossi M, Kim MS, Morgan DG, Small CJ, Edwards CM, Sunter D, Abusnana S, Goldstone AP, Russell SH, Stanley SA, Smith DM, Yagaloff K, Ghatei MA \& Bloom SR (1998) A C-terminal fragment of Agouti-related protein increases feeding and antagonizes the effect of alpha-melanocyte stimulating hormone in vivo. Endocrinology 139, 4428-4431.

Sakurai T, Amemiya A, Ishii M, Matsuzaki I, Chemelli RM, Tanaka H, Williams SC, Richardson JA, Kozlowski GP, Wilson S, Arch JR, Buckingham RE, Haynes AC, Carr SA, Annan RS, McNulty DE, Liu WS, Terrett JA, Elshourbagy NA, Bergsma DJ \& Yanagisawa M (1998) Orexins and orexin receptors: a family of hypothalamic neuropeptides and $\mathrm{G}$ protein-coupled receptors that regulate feeding behavior. Cell $\mathbf{9 2}$, 573-585.

Schwartz MW, Erickson JC, Baskin DG \& Palmiter RD (1998) Effect of fasting and leptin deficiency on hypothalamic neuropeptide $\mathrm{Y}$ gene transcription in vivo revealed by expression of a lacZ reporter gene. Endocrinology 139, 2629-2635.

Schwartz MW, Seeley RJ, Woods SC, Weigle DS, Campfield LA, Burn P \& Baskin DG (1997) Leptin increases hypothalamic pro-opiomelanocortin mRNA expression in the rostral arcuate nucleus. Diabetes 46, 2119-2123.

Schwartz MW, Woods SC, Porte D Jr, Seeley RJ \& Baskin DG (2000) Central nervous system control of food intake. Nature 404, 661-671.

Shimada M, Tritos NA, Lowell BB, Flier JS \& Maratos-Flier E (1998) Mice lacking melanin-concentrating hormone are hypophagic and lean. Nature 396, 670-674.
Shutter JR, Graham M, Kinsey AC, Scully S, Luthy R \& Stark KL (1997) Hypothalamic expression of ART, a novel gene related to agouti, is up-regulated in obese and diabetic mutant mice. Genes and Development 11, 593-602.

Stanley BG, Kyrkouli SE, Lampert S \& Leibowitz SF (1986) Neuropeptide Y chronically injected into the hypothalamus: a powerful neurochemical inducer of hyperphagia and obesity. Peptides 7, 1189-1192.

Steinlechner S, Heldmaier G \& Becker H (1983) The seasonal cycle of body weight in the Djungarian hamster: photoperiod control and influence of starvation and melatonin. Oecologia $\mathbf{6 0}$, 401-405.

Stellar E (1954) The physiology of motivation. Psychological Reviews 61, 5-22.

Thornton JE, Cheung CC, Clifton DK \& Steiner RA (1997) Regulation of hypothalamic proopiomelanocortin mRNA by leptin in ob/ob mice. Endocrinology 138, 5063-5066.

Vaisse C, Clement K, Guy-Grand B \& Froguel P (1998) A frameshift mutation in human MC4R is associated with a dominant form of obesity. Nature Genetics 20, 113-114.

Wardle J S (1999) Aetiology of obesity VIII: Psychological factors. Obesity. British Nutrition Foundation Report, pp. 83-91. Oxford: Blackwell Science.

Yeo GS, Farooqi IS, Aminian S, Halsall DJ, Stanhope RG \& O'Rahilly S (1998) A frameshift mutation in MC4R associated with dominantly inherited human obesity. Nature Genetics $\mathbf{2 0}$, 111-112.

Zhang Y, Proenca R, Maffei M, Barone M, Leopold L \& Friedman JM (1994) Positional cloning of the mouse obese gene and its human homologue. Nature 372, 425-432. 